\title{
ANALISIS FAKTOR-FAKTOR YANG MEMPENGARUHI KEPUASAN KERJA PEGAWAI KONTRAK DI KANTOR CAMAT BULELENG
}

\author{
Kadek Donny Hermawan ${ }^{1}$, lyus Akhmad Haris ${ }^{1}$, Kadek Rai Suwena \\ Program Studi Pendidikan Ekonomi \\ Universitas Pendidikan Ganesha \\ Singaraja, Indonesia
}

\begin{abstract}
e-mail: \{donnyhermawan545@gmail.com ${ }^{1}$, akhmad.haris@undiksha.ac.id ${ }^{1}$, rai.suwen@undiksha.ac.id $\left.{ }^{2}\right\} @ u n d i k s h a . a c . i d$
\end{abstract}

\begin{abstract}
Abstrak
Tujuan penelitian ini adalah untuk mengetahui faktor-faktor yang mempengaruhi kepuasan kerja dan faktor yang paling dominan mempengaruhi kepuasan kerja pegawai kontrak kantor Camat Buleleng. Penelitian ini merupakan jenis penelitian kuantitatif dengan pendekatan faktorial. Data dikumpulkan dengan menggunakan kuesioner kemudian diolah dengan tehnik analisis faktor menggunakan program spss 16 for windows. Hasil penelitian menunjukkan bahwa terdapat 7 faktor yang mempengaruhi kepuasan kerja pada pegawai kontrak di kantor Camat Buleleng yakni balas jasa yang adil dan layak dengan nilai eigenvalue sebesar 58.636, penempatan yang sesuai dengan keahlian dengan nilai eigenvalue 16,632, berat ringannya pekerjaan dengan nilai eigenvalue sebesar 9,526, suasana dan lingkungan kerja dengan nilai eigenvalue sebesar 8,064 , peralatan yang menunjang pelaksanaan pekerjaan dengan nilai eigenvalue sebesar 4,189, sikap pimpinan dalam kepemimpinannya dengan nilai eigenvalue sebesar 2,447, dan sifat pekerjaan monoton atau tidak dengan nilai eigenvalue sebesar 0,507. Dari 7 faktor tersebut, faktor yang paling dominan mempengaruhi kepuasan kerja pada pegawai kontrak di kantor Camat Buleleng adalah faktor balas jasa yang adil dan layak dengan nilai eigenvalue terbesar yaitu 58,636.
\end{abstract}

Kata kunci: Kepuasan kerja, Pegawai kontrak

\begin{abstract}
This research aimed to know the factors wich affect work satisfaction and the most dominant factor which affects work satisfaction of Buleleng subdistrict's employees. This research is a quantitative research with factorial approach. The data was collected using questioner then analyzed with factor analysis technic using the program of spss 16 for windows. Result of this research shows there are 7 factors which affect work satisfaction of Buleleng subdistrict's employees; fair and proper service for the employees with the eigenvalue score equal 58,636 , placement of the employees according to their skills with the eigenvalue score equal 16,632, difficulties level of job with the eigenvalue score 9,526, atmosphere and work society with the eigenvalue score equal 8,064, equipment support for work's activity with the eigenvalue score equal 4,189 , leader's attitude with the eigenvalue score equal 2,447, and kinds of job whether it is monotonous or not with the eigenvalue score equal 0.507 . From those 7 factors, the most dominant factor which affects work satisfaction of Buleleng subdistrict's employees is the factor of fair and proper service for the employees with the eigenvalue score equal 58,636.
\end{abstract}

Keywords: Work satisfaction, Contract employees 


\section{PENDAHULUAN}

Manusia dalam masyarakat yang berkembang, seperti Indonesia, memandang kerja adalah sesuatu yang mulia karena bekerja merupakan tugas yang terkuat dengan kewajiban sebagai warga negara yang baik tersebut. Demikian juga halnya dalam suatu organisasi, unsur manusia sangat menentukan sekali kerena berjalan tidaknya suatu organisasi kearah pencapaian tujuan yang ditentukan tergantung pada kemampuan manusia untuk menggerakkan organisasi tersebut.

Pegawai adalah seseorang yang melakukan penghidupan dengan bekerja dalam kesatuan organisasi baik kesatuan pemerintah maupun kesatuan kerja swasta. Agar organisasi berjalan dengan baik maka pegawai harus memberikan prestasi kerja dan memproleh kompensansi yang diberikan oleh instansi atau perusahaan (Soedaryono, 2000). Kepuasan kerja pada seorang pegawai adalah seperangkat keinginan, kebutuhan, hasrat dan pengalaman masa lalu yang menyatu membentuk harapan kerja. (Hasibuan 2012) Kepuasan kerja menunjukkan kesesuaian antara harapan seseorang yang timbul dan imbalan yang disediakan pekerjaan, Kepuasan kerja adalah reaksi para pegawai terhadap pekerjaannya, yang timbul berdasarkan penilaian terhadap situasi kerja. Kepuasan kerja berkaitan pula dengan hal-hal yang dapat menyenangkan atau perasaan positif yang merupakan akibat dari penghargaan terhadap pekerjaan seseorang. Kepuasan kerja pada dasarnya merupakan hal yang bersifat individual, setiap individu memiliki tingkat kepuasan kerja yang berbeda- beda sesuai dengan keinginan dan sistem nilai yang dianutnya. Semakin banyak aspek dalam pekerjaannya yang sesuai dengan keinginan dan sistem nilai yang dianut individu, semakin tinggi tingkat kepuasan yang didapat. Demikian pula sebaliknya, semakin banyak aspek dalam pekerjaannya yang tidak sesuai dengan keinginan dan sistem nilai yang dianut individu, semakin rendah tingkat kepuasan yang didapat. Dengan demikian, kepuasan kerja merupakan evaluasi yang menggambarkan seseorang atas perasaan sikapnya, senang atau tidak senang, puas atau tidak puas dalam bekerja.

Menurut Rivai (2004) kepuasan kerja adalah penilaian dari pekerja tentang seberapa jauh pekerjaannya secara keseluruhan memuaskan kebutuhannya. Kepuasan kerja juga adalah sikap umum yang merupakan hasil dari beberapa sikap khusus terhadap faktor-faktor pekerjaan, penyesuaian diri, dan hubungan sosial individu di luar kerja. Selanjutnya dalam Kenneth and Yuki (2005:136) ada dua faktor yang dikemukakan oleh Herzberg, teori ini menjelaskan bahwa kepuasan kerja dipengaruhi oleh faktor "hygiene factors dan Satisfiers. Hygiene factors menitik beratkan kepada faktor yang menunjang langsung pekerjaan seperti halnya gaji, pegawasan, hubungan antar pribadi, kondisi kerja dan status. Sedangkan Satisfiers adalah karakteristik pekerjaan yang relevan dengan kebutuhan-kebutuhan urutan lebih tinggi seseorang serta perkembangan psikologisnya, mencakup pekerjaan yang menarik penuh tantangan, kesempatan untuk berprestasi, penghargaan dan promosi.

Selanjutnya lingkungan kerja merupakan salah satu faktor yang mendukung terciptanya kepuasan kerja bagi karyawan. Hubungan komunikasi sesama karyawan yang kurang harmonis, Kurang luasnya ruangan sehingga karyawan tidak leluasa bergerak dan tidak adanya tempat untuk istirahat. Seharusnya kondisi lingkungan kerja dalam perusahaan yang mencakup aspek fisik dan non fisik yang perlu diperhatikan karena dapat memberikan umpan balik kepada perusahaan tersebut, tumbuhnya lingkungan kerja yang nyaman dan menyenangkan akan membuat karyawan lebih termotivasi untuk bekerja. Pengukuran kinerja organisasi tidak dapat terlepaskan dari kondisi kepuasan kerja para karyawan, karena karyawan merupakan salah satu aset organisasi, merupakan bagian yang tak terpisahkan, dan bahkan menjadi yang utama dari stakeholders yang ada. Kepuasan kerja merupakan komponen yang integral dalam iklim organisasi dan merupakan elemen yang penting dalam manajemen sumber daya manusia. Robbin (2008:141) 
Kepuasan yang tinggi akan mengarahkan pada tingkat turn over dan absensi yang rendah karena individu yang puas terdorong untuk bekerja lebih baik disebabkan kebutuhan pentingnya terpuaskan. Ketika seorang karyawan merasakan kepuasan dalam bekerja maka seorang karyawan akan berupaya semaksimal mungkin menyelesaikan pekerjaannya, yang akhirnya akan menghasilkan kualitas pelayanan yang tinggi. Menyadari pentingnya kepuasan kerja karyawan dalam mendukung tingginya produktivitas, pokok permasalahan dalam penelitian ini ingin mengetahui faktor-faktor yang mempengaruhi kepuasan kerja. Faktor-faktor yang menyebabkan kepuasan kerja sangat beragam baik bersumber dari faktor finansial maupun non finansial.

Sebagai salah satu kabupaten di Bali, kabupaten Buleleng memiliki 9 Kecamatan. Kecamatan merupakan pembagian wilayah administratip di Indonesia di bawa Kabupaten atau kota. Kecamatan terdiri atas desa-desa atau kelurahan. Khususnya untuk Kecamatan Buleleng memiliki 29 desa. Kecamatan Buleleng merupakan pelaksana kewenangan pemerintahanan dilimpahkan oleh Bupati untuk menangani sebagian unsur otonomi daerah, menyelenggarakan ketentraman dan pelaksaan kepada masyarakat yang lingkup tugasnya khusus di Kecamatan Buleleng. Berdasarkan observasi awal yang dilakukan di kantor Camat Buleleng tercatat ada 37 pegawai kontrak.

Dari asil wawancara awal yang saya lakukan kepada staf Kecamatan Buleleng didapat bahwa masih ada beberapa pegawai yang memiliki tingkat kemalasan dalam bekerja. Kemalasan disini dapat diartikan dengan datang terlambat maupun penyelesaian tugas yang tidak tepat waktu, serta masih ada beberapa pegawai yang tidak berada di dalam kantor pada saat jam kerja. Padahal pegawai-pegawai di Kecamatan Buleleng ini telah diberikan fasilitas ruang kerja yang memadai. Terlepas dari permasalahan di atas, ini merupakan kondisi dimana kebutuhan pegawai harus diperhatikan dan dipenuhi agar terus dapat bekerja dan memberikan kontribusi yang lebih agar tercapainya kepuasan dalam bekerja. Kinerja dari pegawai tersebut akan baik bila faktor kepuasan kerjanya terpenuhi, terpenuhinya kepuasan kerja pegawai kontrak di Kecamatan Buleleng diduga akan berdampak pada motivasi kerja yang tinggi dan tingkat produktivitas kerja yang optimal. Serta dengan mewujudkan tingkat kepuasan kerja yang tinggi akan menjadi prasyarat bagi peningkatan kinerja pegawai kontrak di Kecamatan Buleleng secara optimal. Namun keadaan di lapangan belum memperlihatkan adanya motivasi kerja yang tinggi pada pegawai di Lingkungan Kantor Kecamatan Buleleng, khususnya bagi pegawai kontrak. Hal ini dapat dilihat dari angka absensi yang masih rendah pada pegawai kontrak di Kecamatan Buleleng.

Berdasarkan latar belakang masalah yang sudah dikemukakan sebelumnya maka peneliti tertarik untuk meneliti "Analisis Faktor-faktor yang Mempengaruhi kepuasan kerja pada pegawai kontrak di Kantor Camat Buleleng ".Masalah yang akan dibahas pada penelitian ini adalah pertama, faktor yang mempengaruhi kepuasan kerja pada pegawai kontrak di Kantor Camat Buleleng. Kedua, faktor apakah yang paling dominan mempengaruhi kepuasan kerja pada pegawai kontrak di Kantor Camat Buleleng. Adapun tujuan dari penelitian ini adalah Pertama, untuk mengetahui faktor-faktor apa saja yang mempengaruhi kepuasan kerja pada pegawai kontrak di Kantor Camat Buleleng. Kedua, untuk mengetahui faktor manakah yang paling dominan mempengaruhi kepuasan kerja pada pegawai kontrak di Kantor Camat Buleleng.

\section{METODE}

Rancangan penelitian yang digunakan dalam penelitian ini adalah jenis rancangan penelitian faktorial. Menurut Sugiyono (2008) analisis faktor adalah suatu teknik yang digunakan untuk menganalisis tentang saling ketergantungan (interindependence) dari beberapa variabel secara simultan menjadi sejumlah faktor yang lebih sedikit dari variabel yang diteliti. Penelitian ini dilakukan untuk mencari faktor-faktor yang mempengaruhi kepuasan kerja pada 
pegawai kontrak di Kantor Camat Buleleng dan untuk mengetahui faktor mana yang paling dominan yang mempengaruhi kepuasan kerja pada pegawai kontrak di Kantor Camat Buleleng.

Lokasi penelitian dengan judul analisis faktor-faktor yang mempengaruhi Kepuasan kerja pada pegawai Kontrak di Kantor Camat Buleleng, bertempat di JL Kartini No 4A Singaraja.

Menurut Arikunto (2007) Subyek penelitian merupakan sesuatu yang sangat penting kedudukanya di dalam penelitian, subjek penelitian harus ditata sebelum peneliti siap untuk mengumpulkan data. Subjek penelitian dapat berupa benda, hal atau orang. Dengan demikian subjek penelitian ini adalah seluruh pegawai kontrak di Kantor Camat Buleleng. Menurut sugiyono (2002) Obyek penelitian merupakan sesuatu yang menjadi pemusatan dalam kegiatan penelitian, atau dengan kata lain segala sesuatu yang menjadi sasaran penelitian. Sehingga objek dalam penelitian ini adalah faktor-faktor yang mempengaruhi kepuasan kerja pada pegawai kontrak di Kantor Camat Buleleng. Jenis data yang dipergunakan dalam penelitian ini adalah data kuantitatif. Adapun sumber data dalam penelitian ini adalah sebagai berikut. Pertama, Jenis data kualitatif merupakan data yang dinyatakan dalam bentuk kata-kata melalui kuisioner mengenai faktor-faktor yang mempengaruhi kepuasan kerja pada pegawai kontrak di Kantor Camat Buleleng. Kedua, Sumber data yang digunakan dalam penelitian ini adalah data primer dan data sekunder. Data primer dalam penelitian ini berupa faktor-faktor yang mempengaruhi kepuasan kerja pada pegawai kontrak di Kantor Camat Buleleng. Data sekunder dalam penelitian ini berupa data yang diperoleh dari dokumen atau catatan pihak Kantor Camat Buleleng mengenai jumlah pegawai kontrak.

Metode pengumpulan data yang digunakan dalam penelitian ini yaitu (a) metode angket atau kuisioner dan (b) metode dokumentasi. Pertama, kuisioner (angket) merupakan metode pengumpulan data yang dilakukan dengan memberikan daftar pertanyaan kepada responden untuk dijawab. Metode ini digunakan untuk mengumpulkan data mengenai faktor-faktor yang mempengaruhi kepuasan kerja pada pegawai kontrak di Kantor Camat Buleleng. Skala pengukuran yang digunakan dalam penelitian ini adalah skala likert. Skala likert merupakan skala yang mengukur sikap, pendapat dan persepsi seseorang maupun sekelompok orang terhadap fenomena yang terjadi di lapangan Sugiyono (2009). Adapun 5 alternatif jawaban yang memiliki skor penilaian sebagai berikut. Jika jawaban Sangat Setuju (SS) di beri skor 5, Jika jawaban Setuju (S) di beri skor 4, Jika jawaban Kurang Setuju (KS) di beri skor 3, Jika jawaban Tidak Setuju (TS) di beri skor 2, Jika jawaban Sangat Tidak Setuju (STS) di beri skor 1

Instrument penelitian yang menggunakan skala likert dapat dibuat dalam bentuk checklist atau pilihan ganda. Sebelum digunakan untuk memperoleh data di lapangan, terlebih dahulu harus diuji tingkat validitas dan reliabelitasnya.

Menurut Sugiyono (2011) pengujian validitas dapat dilakukan dengan menggunakan korelasi product moment. Uji validitas dalam penelitian ini dilakukan dengan menggunakan program SPSS versi 16.0 for windows. Jika nilai $r<0,361$ maka dinyatakan tidak valid dan jika $r>0,361$ maka dianggap memenuhi syarat (valid). Uji validitas dalam penelitian ini dilakukan dengan menggunakan program SPSS 16.0 for windows. Uji reliabelitas menunjukkan sejauh mana instrument dapat memberikan hasil pengukuran yang konsisten apabila pengukuran dilakukan secara berulangulang. Nilai batas yang diperkenalkan untuk menilai atau menguji apakah setiap variabel dapat dipercaya, handal dan akurat dipergunakan formula Koefisien Alpha dari Cronbach. Variabel dapat dinyatakan reliabel apabila Koefisien Alpha Cronbach $\geq$ 0,6 . Uji reliabilitas dalam penelitian ini dilakukan dengan menggunakan program SPSS versi 16.0 for windows.

Menurut Supranto (2010) analisis faktor adalah serangkaian prosudur yang digunakan untuk mengurangi dan meringkas data tanpa kehilangan informasi penting atau mereduksi data dari variabel yang banyak diubah menjadi lebih sedikit jumlahnya. Analisis faktor terdiri dari 
beberapa tahap (Suliyanto, 2005), yaitu sebagai berikut.

Langkah pertama Membuat matrik semua data yang masuk dan diolah akan menghasilkan matrik korelasi. Matrik korelasi dapat didefinisikan variabelvariabel tertentu yang tidak mempunyai korelasi dengan variabel lain, sehingga dapat dikeluarkan dari analisis. Untuk menguji ketepatan model analisis faktor, maka dapat digunakan Barllet's test of Sphericity yang dipakai untuk menguji bahwa variabel-variabel dalam sampel berkorelasi dan menunjukkan apakah hubungan antara variabel-variabel signifikan atau tidak. Statistik lain yang berguna adalah pengukuran kelayakan sampel Kaiser Meyer Olkin (KMO), analisis dianggap layak jika besaran KMO nilainya minimal 0,50. Besaran ini digunakan untuk mengukur derajat korelasi antar variabel dengan kriteria Measure of sampling Adequacy (MSA) $\geq 0,50$.

Langkah kedua Menentukan jumlah faktor, variabel disusun kembali berdasarkan pada korelasi hasil langkah pada butir dua untuk menentukan faktor yang diperlukan untuk mewakili data. Untuk menentukan berapa faktor yang dapat diterima secara empirik dapat dilakukan berdasarkan besarnya eigenvalue setiap faktor yang muncul. Semakin besar iegenvalue setiap faktor, maka semakin representatif faktor tersebut untuk mewakili sekelompok variabel.

Rotasi faktor diperlukan jika metode ekstraksi faktor belum menghasilkan faktor utama yang jelas. Tujuan dari rotasi faktor ini agar dapat memperoleh struktur faktor yang lebih sederhana agar mudah diinterpretasikan. Dalam penelitian ini digunakan rotasi varimax. Rotasi varimax adalah metode rotasi orthogonal untuk meminimalisasi jumlah indikator yang mempunyai factor loading tinggi pada tiap faktor.

Langkah ketiga Interpretasi faktor dilakukan dengan mengelompokkan variabel yang mempunyai factor loading tinggi ke dalam faktor tersebut. Untuk menginterpretasikan hasil penelitian ini factor loadingnya adalah minimal 0,5 dan variabel yang memiliki factor loading kurang dari 0,5 maka dikeluarkan dari model.
Langkah menentukan ketepatan model, Tahap terakhir dari analisis faktor adalah menghetahui apakah model mampu menjelaskan dengan baik. Perlu diuji dengan teknik Principal Component Analisis (PCA) yaitu dengan melihat jumlah residual antara korelasi yang diamati dengan korelasi yang direproduksi. Pada penelitian ini pengujian akan dibantu dengan aplikasi SPSS versi 16.0 for windows. Data yang didapat dari kuisioner masih berupa data ordinal sedangkan analisis data yang digunakan untuk membuktikan kebenaran pengujian analisis faktor perlu mengisyaratkan minimal data interval, maka data ordinal tersebut perlu ditingkatkan menjadi data interval. Data ordinal tersebut ditingkatkan skala pengukurannya menjadi skala interval melalui "Method Of Succestive Interval' (MSI).

Rancangan pengujian hipotesis berdasarkan dengan perumusan masalah, tujuan penelitian dan jenis data yang dikumpulkan maka analisis data yang digunakan dalam penelitian ini adalah analisis faktor. Sesuai dengan hipotesis konseptual yang diajukan, hipotesis tersebut merupakan dimensi untuk menjelaskan faktor utama yang digambarkan dalam sebuah paradigma. Dimensi tersebut yaitu pertama balas jasa yang adil dan layak, kedua penempatan yang sesuai dengan keahlian, ketiga berat ringannya pekerjaan, keempat suasana dan lingkungan pekerjaan, kelima peralatan yang menunjang pelaksanaan pekerjaan, keenam sikap pimpinan dalam kepemimpinannya, kejutuh Sifat pekerjaan monoton atau tidak.

Menguji matriks korelasi menggunakan Barlett's test of Sphericity dengan koefisien KMO yang telah tersedia dalam SPSS versi 16.0 for windows. Jika hasil pengujian statistik Barlett's test of Sphericity signifikan dan hasil perhitungan koefisien $\mathrm{KMO}>0,50$ maka persyaratan pengujian analisis faktor untuk menentukan faktor yang menjelaskan kepuasan kerja pada pegawai kontrak di kantor Camat Buleleng. Untuk menentukan banyaknya faktor yang menjelaskan kepuasan kerja pada pegawai kontrak di Kantor Camat Buleleng dapat dilakukan dengan memilih faktor atau komponen utama yang memiliki 
parameter akar karakteristik terkecil (eigenvalue) $>1$.

Untuk menentukan dimensi atau faktor yang mempengaruhi kepuasan kerja pada pegawai kontrak di Kantor Camat Buleleng digunakan faktor atau komponen utama yang paling mendominasi, maka akan digunakan parameter koefisien varimax rotation dan dimensi atau faktor kepuasan kerja pada pegawai kontrak di kantor Camat Buleleng yang paling mendekati + 1 atau mendekati -1 .

\section{HASIL DAN PEMBAHASAN}

Berdasarkan tujuan dalam penelitian ini yaitu untuk mengetahui faktor-faktor yang mempengaruhi serta faktor mana yang paling dominan mempengaruhi Kepuasan Kerja Pada Pegawai Kontrak di Kantor Camat Buleleng, maka dilakukan analisis menggunakan analisis faktor dengan bantuan program SPSS for Windows versi 16.0. Adapun hasil perhitungan pengujian menggunakan analisis faktor dapat dijelaskan sebagai berikut
Analisis faktor digunakan untuk menganalisis hipotesis pertama penelitian dengan memasukkan semua total nilai dari masing-masing dimensi-dimensi yang ada pada faktor-faktor tersebut terhadap total skor item. Skor dari masing-masing faktor yang telah terjabar ke dalam dimensidimensi terlebih dahulu ditransformasikan ke dalam data interval, kemudian dilakukan langkah-langkah dalam analisis faktor antara lain, membuat matrik korelasi, penentuan jumlah faktor, rotasi faktor, interpretasi faktor, dan model fit (ketepatan model)

Selanjutnya untuk mengukur kecukupan sampel dalam penelitian ini digunakan Kaiser-Mayer-Oilkin (KMO) and Bartlett's Test of Sphericity yang bertujuan untuk menguji derajat interkorelasi antara variabel dan ketepatan pemakaian analisis faktor, serta untuk mengetahui kecukupan sampel atau pengukuran kelayakan sampel pada analisis faktor dengan syarat jika nilai KMO > 0,5 dan uji Bartlett's Test of Sphericity apabila nilai signifikan $<0,05$ Adapun hasil uji KMO dan Bartlett's Test of Sphericity seperti nampak pada tabel 1.

Table 1. Hasil uji KMO and Bartlett's Test of Sphericity

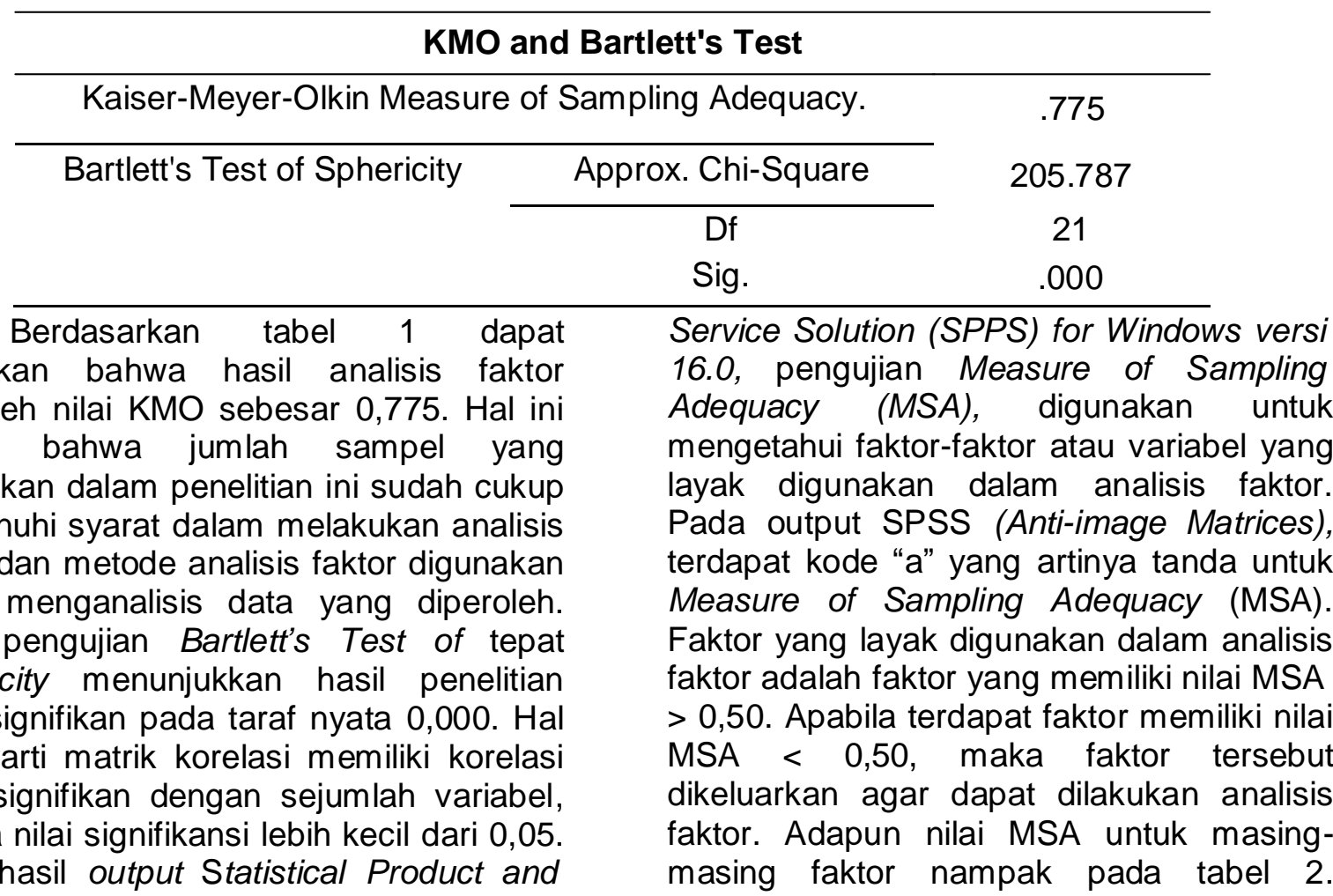


p-ISSN : 2599-1418

e-ISSN : 2599-1426
Jurnal Pendidikan Ekonomi Undiksha

Volume 10 No. 2 Tahun 2018
Berdasarkan tabel 2, dapat diketahui bahwa faktor-faktor dalam penelitian memiliki MSA > 0,50 dan faktor tersebut adalah balas jasa yang adil dan layak $\left(X_{1}\right)$, penempatan yang sesuai dengan keahlian $\left(X_{2}\right)$, berat ringannya pekerjaan $\left(X_{3}\right)$, suasana dan lingkungan pekerjaan $\left(\mathrm{X}_{4}\right)$, peralatan yang menunjang pelaksanaan pekerjaan $\left(X_{5}\right)$, sikap pimpinan dalam kepemimpinannya $\left(X_{7}\right)$, dan sifat pekerjaan monoton atau tidak $\left(X_{7}\right)$. Dengan demikian faktor-faktor tersebut dapat dianalisis secara keseluruhan dan dapat dilanjutkan.

Untuk menentukan banyaknya faktor yang mempengaruhi kepuasan kerja, dapat dijelaskan oleh nilai persentase dari masing-masing faktor. Nilai Total Variance Explained digunakan untuk mengetahui persentase dari ketuju faktor yang dianalisis. Hasil analisis faktor melalui SPSS menunjukkan persentase dari masing-masing faktor dapat dilihat pada tabel

Table 2. Hasil Analisis Measure of Sampling Adequacy (MSA)

\begin{tabular}{|c|c|c|}
\hline Faktor & Nilai MSA & Keputusan \\
\hline $\begin{array}{l}\text { balas jasa yang adil dan } \\
\text { layak }\end{array}$ & $0,768>0,50$ & $\begin{array}{l}\text { Dapat digunakan untuk analisis } \\
\text { faktor }\end{array}$ \\
\hline $\begin{array}{l}\text { penempatan yang sesuai } \\
\text { dengan keahlian }\end{array}$ & $0,631>0,50$ & $\begin{array}{l}\text { Dapat digunakan untuk analisis } \\
\text { faktor }\end{array}$ \\
\hline berat ringannya pekerjaan & $0,708>0,50$ & $\begin{array}{l}\text { Dapat digunakan untuk analisis } \\
\text { faktor }\end{array}$ \\
\hline $\begin{array}{l}\text { suasana dan lingkungan } \\
\text { pekerjaan }\end{array}$ & $0,771>0,50$ & $\begin{array}{l}\text { Dapat digunakan untuk analisis } \\
\text { faktor }\end{array}$ \\
\hline $\begin{array}{l}\text { peralatan yang } \\
\text { menunjang pelaksanaan } \\
\text { pekerjaan }\end{array}$ & $0,886>0,50$ & $\begin{array}{l}\text { Dapat digunakan untuk analisis } \\
\text { faktor }\end{array}$ \\
\hline $\begin{array}{l}\text { sikap pimpinan dalam } \\
\text { kepemimpinannya }\end{array}$ & $0,915>0,50$ & $\begin{array}{l}\text { Dapat digunakan untuk analisis } \\
\text { faktor }\end{array}$ \\
\hline $\begin{array}{l}\text { sifat pekerjaan monoton } \\
\text { atau tidak }\end{array}$ & $0,815>0,50$ & $\begin{array}{l}\text { Dapat digunakan untuk analisis } \\
\text { faktor }\end{array}$ \\
\hline
\end{tabular}

Tabel 3. Hasil Analisis Total Variance Explained

Total Variance Explained

\begin{tabular}{|c|c|c|c|c|c|c|c|c|c|}
\hline \multirow[b]{2}{*}{$\begin{array}{l}\text { Co } \\
\text { mpo } \\
\text { nent }\end{array}$} & \multicolumn{3}{|c|}{ Initial Eigenvalues } & \multicolumn{3}{|c|}{$\begin{array}{l}\text { Extraction Sums of } \\
\text { Squared Loadings }\end{array}$} & \multicolumn{3}{|c|}{$\begin{array}{l}\text { Rotation Sums of Squared } \\
\text { Loadings }\end{array}$} \\
\hline & & $\begin{array}{l}\% \text { of } \\
\text { Varianc } \\
\mathrm{e}\end{array}$ & $\begin{array}{l}\text { Cumulati } \\
\text { ve } \%\end{array}$ & Total & $\begin{array}{l}\% \text { of } \\
\text { Varianc } \\
\mathrm{e}\end{array}$ & $\begin{array}{l}\text { Cumul } \\
\text { ative } \\
\%\end{array}$ & Total & $\begin{array}{l}\% \text { of } \\
\text { Variance }\end{array}$ & $\begin{array}{l}\text { Cumulati } \\
\text { ve } \%\end{array}$ \\
\hline 1 & 4.104 & 58.636 & 58.636 & 4.104 & 58.636 & 58.636 & 3.195 & 45.645 & 45.645 \\
\hline 2 & 1.164 & 16.632 & 75.267 & 1.164 & 16.632 & 75.267 & 2.074 & 29.622 & 75.267 \\
\hline 3 & .667 & 9.526 & 84.793 & & & & & & \\
\hline 4 & .564 & 8.064 & 92.857 & & & & & & \\
\hline 5 & .293 & 4.189 & 97.046 & & & & & & \\
\hline 6 & .171 & 2.447 & 99.493 & & & & & & \\
\hline 7 & .035 & .507 & 100.000 & & & & & & \\
\hline
\end{tabular}


Berdasarkan tabel 3, dapat diketahui bahwa persentase dari faktor pertama balas jasa yang adil dan layak memiliki eigenvalue sebesar 4,104 dengan nilai variance sebesar 58,636\%, kedua faktor penempatan yang sesui dengan keahlian memiliki eigenvalue sebesar 1,164 dengan nilai variance sebesar $16,632 \%$, ketiga faktor berat ringannya pekerjaan memiliki eigenvalue sebesar 0,667 dengan nilai variance sebesar $9,526 \%$, keempat faktor suasana dan lingkungan pekerjaan memiliki eigenvalue sebesar 0,564 dengan nilai variance sebesar $8,064 \%$, keliam faktor peralatan yang menunjang pelaksanaan pekerjaan memiliki eigenvalue sebesar 0,293 dengan nilai variance sebesar $4,189 \%$ keenam faktor sikap pimpinan dalam kepemimpinannya memiliki eigenvalue sebesar 0,171 dengan nilai variance sebesar 2,447 dan ketujuh faktor sifat pekerjaan manoton atau tidak memiliki eigenvalue sebesar 0,035 dengan nilai variance sebesar 0,507. Menurut Yamin dan Kurniawan (2009) total variance explained menerangkan nilai persen dari varians yang mampu diterangkan oleh banyaknya faktor yang terbentuk. Jadi, kelima faktor-faktor tersebut mempengaruhi kepuasan kerja pada pegawai kontrak di Kantor Camat Buleleng

Untuk menjelaskan faktor yang memiliki total eigenvalue $>1$ terhadap kepuasan kerja pada pegawai kontrak di kantor Camat Buleleng, dapat dilakukan melalui ekstrasi faktor. Ekstrasi faktor dapat dijelaskan oleh total persentase variance dari masing-masing faktor utama. Faktorfaktor utama tersebut memiliki nilai parameter akar karakteristik terkecil eigenvalue $>1$. Untuk mengetahui distribusi dimensi yang belum dirotasi ke dalam faktor yang telah terbentuk maka dapat dilihat pada output SPSS 16.0 for windows (Rotated Component Matrix). Faktor yang memiliki total eigenvalue $>1$ terhadap kepuasan kerja pada pegawai kontrak di Kantor Camat Buleleng dapat dilihat pada tabel

Tabel 4. Faktor-Faktor yang Mempengaruhi Kupuasan Kerja Pada Pegawai Kontrak Di Kantor Camat Buleleng

\begin{tabular}{|c|c|c|c|}
\hline & & Varianced & Factor \\
\hline Faktor & EigenValue & $\begin{array}{l}\text { Explained } \\
\text { (\%) }\end{array}$ & Loading \\
\hline Balas jasa yang adil dan layak & 4.104 & 58.636 & .872 \\
\hline $\begin{array}{l}\text { Penempatan yang sesuai dengan } \\
\text { keahlian }\end{array}$ & 1.164 & 16.632 & .869 \\
\hline Berat ringannya pekerjaan & .667 & 9.526 & .784 \\
\hline Suasana dan lingkungan pekerjaan & .564 & 8.064 & .700 \\
\hline $\begin{array}{l}\text { Peralatan yang menunjang } \\
\text { pelaksaan pekerjaan }\end{array}$ & .293 & 4.189 & .689 \\
\hline $\begin{array}{l}\text { Sikap pimpinan dalam } \\
\text { kepemimpinannya }\end{array}$ & .171 & 2.447 & .874 \\
\hline Sifat pekerjaan manoton atau tidak & .035 & .507 & .870 \\
\hline
\end{tabular}

Berdasarkan tabel 4, dapat dijelaskan bahwa faktor yang memiliki eigenvalue > 1 adalah faktor balas jasa yang adil dan layak dan faktor penempatan yang sesuai dengan keahlian. Total nilai varianced explained dari kedua faktor keseluruhan dapat menjelaskan sebesar $75,267 \%$. Dengan demikian $75,267 \%$ dari seluruh faktor yang ada, dapat dijelaskan oleh kedua faktor yang terbentuk. Faktor balas jasa yang adil dan layak memiliki varianced explained $75,267 \%$, artinya bahwa faktor balas jasa yang adil dan layak mampu menjelaskan pengaruhnya terhadap kepuasan kerja sebesar 58,636\%. Faktor penempatan yang sesuai dengan 
p-ISSN : 2599-1418

e-ISSN : 2599-1426
Jurnal Pendidikan Ekonomi Undiksha

Volume 10 No. 2 Tahun 2018 keahlian memiliki varianced explained $16,632 \%$, artinya bahwa faktor penempatan yang sesuai dengan keahlian mampu menjelaskan pengaruhnya terhadap kepuasan kerja 16,632\%.

Menentukan nama faktor yang telah terbentuk untuk masing-masing faktor bersifat subjektif. Menurut Suliyanto (2005) untuk menentukan nama faktor yang telah terbentuk, kadangkala faktor yang memiliki nilai faktor loading tertinggi digunakan untuk memberikan nama faktor, yang dimana semakin tinggi nilai faktor loading maka semakin erat hubungan antara variabel dengan faktor tersebut. Adapun nilai dari faktor loading dapat dilihat pada tabel 5 .
Berdasarkan tabel 5 di atas, dapat dikelompokkan menjadi dua faktor yang telah terbentuk. Masing-masing kelompok faktor tersebut memiliki faktor loading tertinggi di setiap komponen, yaitu faktor satu terbentuk dari faktor suasana dan lingkungan pekerjaan $\left(X_{4}\right)$ sebesar 0,872 , faktor balas jasa yang adil dan layak $\left(X_{1}\right)$ sebesar 0, 869, sikap pimpinan dalam kepemimpinannya $\left(X_{6}\right)$ sebesar 0,784 , faktor peralatan yang menunjang pelaksaan pekerjaan $\left(X_{5}\right)$ sebesar 0,700 , faktor sifat pekerjaan manoton atau tidak $\left(X_{7}\right)$ sebesar 0 , 689. Faktor dua terbentuk dari faktor berat ringannya pekerjaan $\left(X_{3}\right)$ sebesar 0,874 , dan faktor penempatan yang sesuai dengan keahlian $\left(\mathrm{X}_{2}\right)$ sebesar 0,870.

Tabel 5. Hasil Analisis Rotated Component Matrix Rotated Component Matrix ${ }^{a}$

\begin{tabular}{lcc}
\hline & \multicolumn{2}{c}{ Component } \\
\cline { 2 - 3 } & 1 & 2 \\
\hline Suasana dan lingkungan pekerjaan & .872 & .386 \\
Balas jasa yang adil dan layak & .869 & .402 \\
Sikap pimpinan dalam kepemimpinannya & .784 & -.168 \\
Peralatan yang menunjang pelaksaan pekerjaan & .700 & .288 \\
Sifat pekerjaan manoton atau tidak & .689 & .363 \\
Berat ringannya pekerjaan & .299 & .874 \\
Penempatan yang sesuai dengan keahlian & .106 & .870 \\
\hline
\end{tabular}

Tabel 6. Matriks Rotasi Hasil Analisis Faktor

\begin{tabular}{|c|c|c|}
\hline \multirow{2}{*}{ Dimensi atau faktor kepuasan kerja } & \multicolumn{2}{|c|}{ Varimax Rotation (\%) } \\
\hline & $(1)$ & (2) \\
\hline $\begin{array}{l}\text { Balas jasa yang adil dan layak } \\
\text { Penempatan yang sesuai dengan keahlian }\end{array}$ & 58.636 & $\begin{array}{ll}- \\
16.632\end{array}$ \\
\hline
\end{tabular}

Berdasarkan pengujian hipotesis penelitian, untuk menentukan dimensi atau faktor yang paling dominan kepuasan kerja pada pegawai kontrak di kantor Camat Buleleng, digunakan parameter koefisien varimax mendekati +1 dan -1 . Nilai yang mendekati +1 diawali oleh nilai 0,5 sedangkan nilai yang mendekati -1 diawali oleh -0,5. Secara lebih rinci hasil ringkasan rotasi dari matrik faktor memuat nilai varimax rotation, dapat dilihat pada tabel 6 .
Berdasarkan tabel 6, dapat diketahui bahwa faktor yang paling dominan yang mempengaruhi kepuasan kerja pada pegawai kontrak di kantor Camat Buleleng adalah faktor Balas jasa yang adil dan layak dengan nilai varimax rotation 58,636\%. Artinya kejelasan dari dimensi atau faktor kepuasan kerja pada pegawai kontrak di kantor Camat Buleleng yang paling mendominasi sebesar 58,636\%. 
Berdasarkan hasil penelitian yang diperoleh mengenai faktor-faktor yang mempengaruhi kepuasan kerja pegawai kontrak di Kantor Camat Buleleng dipengaruhi oleh faktor balas jasa yang adil dan layak, penempatan yang sesuai dengan keahlian, berat ringannya pekerjaan, suasana dan lingkungan pekerjaan, peralatan yang menunjang pelaksanaan pekerjaan, sikap pimpinan dalam kepemimpinannya dan sifat pekerjaan monoton atau tidak. Variance masing-masing faktor yaitu, faktor balas jasa yang adil dan layak berpengaruh sebesar $58,636 \%$, faktor penempatan yang sesuai dengan keahlian berpengaruh sebesar $16,632 \%$, faktor berat ringannya pekerjaan sebesar $9,526 \%$, faktor suasana dan lingkungan pekerjaan berpengaruh $8,064 \%$, faktor peralatan yang menunjang pelaksanaan pekerjaan berpengaruh sebesar 4,189\%, faktor sikap pimpinan dalam kepemimpinannya sebesar 2,447\% dan faktor sifat pekerjaan monoton atau tidak sebesar 0,507

Ketujuh faktor tersebut yang mempengaruhi kepuasan kerja pegawai kontrak di Kantor Camat Buleleng sesuai dengan teori yang dinyatakan oleh Hasibuan,2007:203, bahwa faktor balas jasa yang adil dan layak, penempatan yang sesuai dengan keahlian, berat ringannya pekerjaan, suasana dan lingkungan pekerjaan, peralatan yang menunjang pelaksanaan pekerjaan, sikap pimpinan dalam kepemimpinannya dan sifat pekerjaan monoton atau tidak adalah faktor-faktor yang mempengaruhi kepuasan kerja pegawai kontrak, dari tujuh faktor kepuasan kerja tersebut, yang paling dominan mempengaruhi kepuasan kerja pegawai kontrak di Kantor Camat Buleleng adalah faktor balas jasa yang adil dan layak yang mempunyai nilai variance sebesar $58,636 \%$. Seperti yang kita ketahui bahwa balas jasa yang adil dan layak bisa disebut dengan gaji, maka dari itu jika gaji yang diberikan kepada pegawai kontrak itu tinggi akan mampu meningkatkan kinerja pegawai kontrak begitu pula sebaliknya, jika gaji yang diberikan kepada pegawai kontrak itu rendah atau di bawah Upah Minimum Regional (UMR) akan menggurangi kinerja pegawai kontrak dan juga menggurangi semangat kerja pegawai kontrak di Kantor Camat Buleleng.

\section{DAFTAR PUSTAKA}

Arikunto, S. 2007. Prosedur Penelitian Suatu Pendekatan Praktek Edisi. Jakarta, Rineka Apta.

Hasibuan, Malayu S. P, 2007. Manajemen Sumber Daya Manusia. Jakarta : Cetakan 9. PT. Bumi Aksara

Hasibuan, Malayu S. P 2012, Manajemen Sumber Daya Manusia Cetakan Keenam Belas, Jakarta : PT. Bumi Aksar

Kenneth N. Wexley Dan Yuki, Gary A. 2005. Perilaku Organisasi dan Psikologi Personalia, Jakarta: PT Asdi Mahasatya.

Praktik, Edisi Pertama, Jakarta: Penerbit PT. Raja Grafindo Persada.

Rivai, Veithzal. 2004, "Manajemen Sumber Daya Manusia untuk Perusahaan Cetakan Pertama, Jakarta, PT. Raja GrafindoPersada

Robbin SP , dan Judge. 2008 Perilaku Organisasi, Jakarta : Salemba

Soedaryono 2000, Tata Laksana Kantor, Jakarta: Departemen Pendidikan dan Kebudayaan.

Sugiyono 2009, Metoda Penelitian Kuantitatif, Kualitatif Dan $R \& D$, Bandung: CV Alfabeta.

Sugiyono, 2008.Metode Penelitian Bisnis. Cetakan. Bandung: Alfabeta

Sugiyono. 2002. Metode Penelitian Administrasi, Bandung: CV Alfabeta.

Sugiyono. 2004. Statistika untuk Penelitian. Bandung : Alfabeta.

Sugiyono. 2007. Metode Penelitian Kuantitatif dan R\&D. Bandung: Alfabeta.

Suliyanto . 2005, Analisis Data dalam Aplikasi Pemasaran, Bogor: Ghalia Indonesia. 
p-ISSN : 2599-1418

e-ISSN : 2599-1426
Jurnal Pendidikan Ekonomi Undiksha

Volume 10 No. 2 Tahun 2018

Suliyanto. 2012. Analisis Statistik-

Pendekatan Praktis dengan Microsoft Excel. Yogyakarta, Indonesia: Andi- Yogyakarta

Supranto J. 2010. Statistik Teori dan Aplikasi. Jakarta : UI Press.

Yamin Sofyan, Kurniawan Heri. 2009. SPSS COMPLETE: Tekhnik Analisis Statistik Terlengkap dengan Sofwere SPSS. Jakarta : Salemba Infotek. 